\title{
Peningkatan Aktivitas dan Hasil Belajar Siswa Kelas IX.2 SMPN 1 IX Koto Sungai Lasi dengan Menggunakan Model Pembelajaran Kooperatif Tipe Group Investigation
}

\author{
Afrilita \\ Guru SMP Negeri 1 IX Koto Sungai Lasi, Kab. Solok
}

\begin{abstract}
Abstrak
Penelitian ini dilatarbelakangi oleh rendahnya aktivitas dan hasil belajar IPA Terpadu siswa di kelas IX.2 SMPN I IX Koto Sungai Lasi. Penelitian ini bertujuan untuk mendeskripsikan peningkatan aktivitas dan hasil belajar IPA Terpadu siswa di kelas IX.2 SMPN 1 IX Koto Sungai Lasi dengan menggunakan model pembelajaran kooperatif tipe Group Investigation (GI). Penelitian ini merupakan Penelitian Tindakan Kelas (PTK) yang terdiri atas dua siklus, yang meliputi: tahap perencanaan, pelaksanaan, observasi, dan refleksi. Subjek penelitian ini adalah siswa IX.2 SMPN 1 IX Koto Sungai Lasi yang berjumlah 21 orang. Teknik pengumpulan data dilakukan dengan cara observasi dan tes hasil belajar yang dianalisis dengan statistik deskriptif, yaitu mencari persentase peningkatan aktivitas dan hasil belajar siswa. Selanjutnya, dapat disimpulkan bahwa model pembelajaran koopertaif tipe Group Investigation (GI) dapat meningkatkan aktivitas dan hasil belajar IPA Terpadu siswa di kelas IX.2 SMPN 1 IX Koto Sungai Lasi.
\end{abstract}

Kata kunci: aktivitas belajar, hasil belajar, pembelajaran kooperatif, group investigation

Copyright (C) 2017 IICET (Indonesia) - All Rights Reserved

Indonesian Institute for Counseling, Education and Theraphy (IICET)

\section{PENDAHULUAN}

Aktivitas pembelajaran merupakan suatu kegiatan yang dilaksanakan untuk membangkitkan minat belajar. Menurut Wasti, S. (2013) minat belajar adalah suatu perasaan senang, perhatian dalam belajar dan adanya ketertarikan siswa kepada pelajaran. Selanjutnya menurut Muldayanti, N. D. (2013) minat belajar merupakan kecenderungan hati yang tinggi terhadap suatu gairah keinginan untuk suatu perubahan yang terjadi pada seseorang dalam melaksanakan kegiatan (belajar) amat bergantung dari kapasitas yang dimiliki. Senada dengan Kontekstual, m. P. P. (2011) juga menjelaskan minat belajar merupakan keinginan dan kesadaran seseorang untuk mengadakan perubahan dalam dirinya ke arah yang lebih baik (ada perkembangan) dengan dinyatakan atau dibuktikan dengan adanya perubahan tingkah laku.

Faktor utama yang mempengaruhi minat dan motivasi belajar adalah cara mengajar guru, karakter guru, suasana kelas tenang dan nyaman, dan fasilitas belajar yang digunakan Aritonang, K. T. (2008). Dapat disimpulkan bahwa minat belajar merupakan bentuk ketertarikan, keinginan siswa untuk melakukan hal, tugas, latihan, yang berkaitan dengan pembelajaran. Dengan meningkatnya minat siswa dalam belajar, maka secara signifikan prestasi hasil belajar pun secara otomatis akan baik.

Berdasarkan Kamus Besar Bahasa Indonesia, minat adalah sebuah keinginan mendasar seseorang secara tulus dalam berbuat, bertindak,menentukan atau melakukan pilihan sesuai dengan kriteria-kriteria yang dimiliki oleh seseorang. Minat juga merupakan suatu kecenderungan hati yang tinggi terhadap sesuatu, juga 
merupakan suatu gairah atau keinginan. Menurut Winkel (1996:24), minat adalah kecenderungan yang menetap dalam subjek untuk merasa tertarik pada bidang/hal tertentu dan merasa senang berkecimpung dalam bidang itu.

Wasti, S. (2013) minat adalah rasa lebih suka dan rasa ketertarikan pada sesuatu hal atau aktivitas tanpa ada yang menyuruh. Minat merupakan adanya perasaan senang, perhatian dalam belajar dan adanya ketertarikan siswa kepada pelajaran. Selanjutnya, Sandjaja, S. (2001) mengemukakan minat adalah perhatian yang kuat, intensif dan menguasai individu secara mendalam untuk tekun melakukan suatu aktivitas. Sejalan dengan Sakti, I., Yuniar Mega, P., \& Eko, R. (2012) yang juga menjelaskan bahwa minat merupakan kecenderungan yang tetap untuk memperhatikan dan mengenang beberapa kegiatan.

Menurut Mappeasse, M. Y. (2009) kegiatan yang dimiliki seseorang diperhatikan terus menerus yang disertai dengan rasa sayang. Dengan demikian, peranan aktivitas belajar dalam menentukan minat menjadi sangat penting/dominan berkaitan dengan upaya peningkatan hasil belajar siswa Nurseto, T. (2012). Kenyataan yang terjadi dalam pembelajaran adalah sering dijumpai hal-hal yang tidak mendukung pencapaian hasil belajar. Hal ini menyebabkan minat atau keinginan siswa dalam belajar menjadi rendah, beberapa kompetensi dasar sebagai tujuan pembelajaran belum tercapai, dan ketidaktercapaian Kriteria Ketuntasan Minimal (KKM) yang diharapkan. Oleh sebab itu, perlu dilakukan upaya atau langkah konkrit untuk meningkatkan minat atau motivasi belajar siswa.

Permasalahan yang sama, terjadi pada siswa kelas IX SMPN 1 IX Koto Sungai Lasi, khususnya siswa di kelas IX.2. Hal ini tampak dari cara belajar pada semester ganjil tahun pelajaran 2015/2016 dan hasil tes pada materi SK/KD 4.1. Menyelidiki gejala kemagnetan dan cara membuat magnet pada mata pelajaran IPA Terpadu pada semester Genap tahun ajaran 2015-2016. Dari data yang ada diperoleh, dapat disimpulkan bahwa pada tes tertulis pertama, hanya ada $37,5 \%$ dari 21 orang siswa yang mendapat nilai 76 ke atas (batas ketuntasan), sedangkan sebagian besar siswa mendapat nilai di bawah 76, bahkan ada yang mendapat nilai 10.

Rendahnya kemampuan para siswa menjadi petunjuk adanya kelemahan sekaligus kesulitan belajar. Hal ini menunjukkan adanya kelemahan dan kesulitan belajar pada materi menyelidiki gejala kemagnetan dan cara membuat magnet yang dihadapi oleh siswa. Selanjutnya, penulis mengidentifikasi penyebab siswa kelas IX.2 'gagal' dalam belajar IPA Terpadu berkaitan dengan kesulitan memahami materi IPA Terpadu. Selama ini, pembelajaran IPA dilakukan dengan tahapan sebagai berikut: (1) memberi tahu materi yang akan dibahas. Contohnya, pada materi menyelidiki gejala kemagnetan dan cara membuat magnet, dengan cara membuatkan urutan materi yang harus dibaca peserta didik di rumah, (2) meminta peserta didik selain membaca materi tersebut juga meringkasnya, (3) diskusi kelas untuk memahami materi yang dirasa sulit untuk dibahas bersama, (4) untuk mudahnya dalam pemahaman sengaja diskusi dilengkapi dengan carta (penayangan gambar) dan demonstrasi yang dipandu oleh guru mata pelajaran, dan (5) menilai hasil tes tertulis. Prosedur tersebut menunjukkan bahwa siswa tidak diberi kesempatan untuk melakukan aktivitas secara individual/kelompok memahami materi melalui tahap presentasi hasil diskusi lebih dahulu guna membangun skemanya tentang isi materi sehingga hasil evaluasi belajarnya masih rendah.

Berdasarkan fenomena-fenomena di atas, maka perlu dicarikan solusi yang tepat agar persoalan minat dan hasil belajar siswa dapat ditingkatkan. Salah satu metode yang tepat adalah metode kooperatif. Pembelajaran kooperatif merupakan suatu pembelajaran kelompok dengan jumlah peserta didik 2-5 orang dengan gagasan untuk saling memotivasi antara anggotanya untuk saling membantu agar tercapainya suatu tujuan pembelajaran yang maksimal. Pembelajaran kooperatif merupakan strategi pembelajaran melalui kelompok kecil siswa yang saling bekerja sama dalam memaksimalkan kondisi belajar untuk mencapai tujuan belajar (Depdiknas, 2003). 
Bern dan Erickson (2001) menyatakan bahwa pembelajaran kooperatif merupakan strategi pembelajaran yang mengorganisir pembelajaran dengan menggunakan kelompok belajar kecil di mana siswa bekerja sama untuk mencapai tujuan belajar". Menurut Johnson (dalam Hasan, 1996) "belajar kooperatif adalah pemanfaatan kelompok kecil (2-5 orang) dalam pembelajaran yang memungkinkan siswa bekerja bersama untuk memaksimalkan belajar mereka dan belajar anggota lainnya dalam kelompok". Agus (2010:54) menyatakan bahwa model pembelajaran kooperatif adalah konsep yang lebih luas meliputi semua jenis kerja kelompok termasuk bentuk-bentuk yang dipimpin oleh guru atau diarahkan oleh guru. Berdasarkan pendapat ahli, dapat dipahami bahwa cooperative learning atau pembelajaran kooperatif adalah suatu model pembelajaran dimana sistem belajar dan bekerja kelompok-kelompok kecil berjumlah 4-6 orang secara kolaboratif sehingga dapat merangsang peserta didik lebih bergairah dalam belajar.

Salah satu tipe metode kooperatif yang dapat digunakan untuk mengatasi persoalan siswa dalam memahami materi IPA Terpadu adalah model pembelajaran kooperatif tipe Group Investigation (selanjutnya disingkat GI). Model pembelajaran kooperatif GI merupakan metode pembelajaran dengan siswa belajar secara kelompok, kelompok belajar terbentuk berdasarkan topik yang dipilih siswa. Pendekatan ini memerlukan norma dan struktur yang lebih rumit daripada pendekatan yang lebih berpusat pada guru. Dalam pembelajaran kooperatif GI siswa dibagi menjadi beberapa kelompok dengan anggota 2-6 orang siswa yang heterogen. Kelompok memilih topik untuk diselidiki dan melakukan penyelidikan yang mendalam atas topik yang dipilih, selanjutnya menyiapkan dan mempresentasikan laporan di depan kelas Sulasti, N. W. (2013).

Dalam implementasi tipe investigasi kelompok guru membagi kelas menjadi kelompok-kelompok dengan anggota-anggota 5-6 siswa yang heterogen. Kelompok disini dapat dibentuk dengan mempertimbangkan keakraban persahabatan atau minat yang sama dalam topik tertentu. Selanjutnya siswa memilih topik untuk diselidiki dan melakukan penyelidikan yang mendalam atas topik yang dipilih. Selanjtnya, siswa menyiapkan dan mempresentasikan laporannya kepada seluruh kelas (Asma dalam Devi, 2013). Penggunaan model pembelajaran ini dapat meningkatkan minat belajar siswa karena pembelajaran dengan metoda ini lebih didasarkan pada menggali informasi yang akan menarik minat siswa terutama dalam hal penyajian materi yang lebih skematis, terperinci, dan lebih konkrit dengan berbagai variasi gambar/tulisan yang menarik perhatian siswa yang ditampilkan dalam belajar.

Berdasarkan permasalahan di atas, maka peneliti menetapkan untuk menerapkan metode kooperatif pada kegiatan pemahaman materi pemanfaatan kemagnetan dalam produk teknologi dan konsep induksi elektromagnetik untuk menjelaskan prinsip kerja alat yang memanfaatkan prinsip induksi elektromagnetik dalam bentuk penelitian tindakan kelas. Adapun alasan pemilihan strategi tersebut sebagai berikut: (1) cooperatif learning tipe group investigation dapat membantu siswa dalam mengatur fokus perhatiannya sehingga menghindarkannya dari pemberian fokus berlebihan pada materi yang kurang penting, atau sebaliknya kurang memberikan perhatian pada materi yang penting, (2) cooperatif learning tipe group investigation memungkinkan siswa dapat melakukan kegiatan memahami materi pemanfaatan kemagnetan dalam produk teknologi dan konsep induksi elektromagnetik untuk menjelaskan prinsip kerja alat yang memanfaatkan prinsip induksi elektromagnetik dengan tujuan yang jelas, yakni menemukan informasi untuk menjawab materi pemanfaatan kemagnetan dalam produk teknologi dan menerapkan konsep induksi elektromagnetik untuk menjelaskan prinsip kerja alat yang memanfaatkan prinsip induksi elektromagnetik, dan (3) dengan dilatihnya siswa membaca materi dan memahaminya sebelum kegiatan pembelajaran dimulai, berarti pembelajaran tidak hanya difokuskan pada hasil, tapi juga pada proses panguasaan keterampilan. Konsep pembelajaran kooperatif ini merupakan solusi alternatif terbaik dan sangat tepat jika diterapkan dalam proses pembelajaran IPA Terpadu karena memberikan berbagai kemudahan dalam belajar, seperti pemahaman konsep, menjadikan proses pembelajaran menjadi lebih menarik dan menyenangkan karena konsep pengemasan yang lebih sederhana. 


\section{METODOLOGI}

Penelitian ini merupakan Penelitian Tindakan Kelas (PTK). Subjek penelitian ini adalah siswa kelas IX.2 SMPN 1 IX Koto Sungai Lasi, Kabupaten Solok, yakni pada semester II tahun pelajaran 2015/2016 yang berjumlah 21 orang. Penelitian ini dilaksanakan di kelas IX.2 SMPN 1 IX Koto Sungai Lasi selama 2 bulan, yaitu pada bulan Januari 2016 s/d Februari 2016. Penelitian ini terdiri atas 2 siklus melalui 4 tahapan, yaitu perencanaan, pelaksanaan, observasi, dan refleksi. Selanjutnya, teknik pengumpulan data dalam penelitian ini menggunakan teknik observasi yang dibantu dengan instrumen format lembaran observasi dan tes hasil belajar yang dibantu dengan instrumen berupa tes tertulis. Selain itu, penganalisisan data penelitian ini menggunakan statistik deskriptif, yaitu mencari persentase atau rata-rata aktivitas dan hasil belajar IPA siswa.

\section{HASIL DAN PEMBAHASAN \\ Peningkatan Aktivitas Belajar}

Observasi yang dilakukan oleh observer bertujuan untuk mengetahui kualitas aktivitas belajar siswa melalui model pembelajaran kooperatif tipe group investigation. Berdasarkan data yang diperoleh dari observer, dapat diketahui bahwa aktivitas belajar siswa pada siklus 1. Hal tersebut dapat dijelaskan dari persentase aktivitas belajar siswa yang telah mengalami peningkatan aktivitas belajar IPA Terpadu jika dibandingkan dengan refleksi awal. Hal ini dapat dilihat dari presentase rata-rata siswa aktif pada siklus 1berikut ini.

a) Siswa yang aktif memperhatikan dengan sungguh-sungguh dari $40 \%$ dan 38\% (kurang ) menjadi $53 \%$ (cukup) dengan rata-rata $44 \%$ (cukup).

b) Siswa yang aktif bertanya/ menjawab pertanyaan pada saat pembelajaran dari $45 \%$ dan $50 \%$ (cukup) menjadi 54\% (cukup) dengan rata-rata 50\% (cukup).

c) Siswa yang aktif mencatat dan membuat kesimpulan dari 53\% dan 60\% (cukup) menjadi $75 \%$ ( baik ) denga rata-rata $63 \%$ (baik).

d) Siswa yang aktif bekerja secara berkelompok dengan teman sekelompok dari $38 \%$ dan $50 \%$ (cukup) menjadi 58\% (cukup) dengan rata-rata $49 \%$ (cukup).

e) Siswa yang menerima bantuan teman atau memberi bantuan kepada teman yang belum faham/ mengerti dari 25\% dan 38\% (kurang) menjadi 50\% (cukup) dengan rata-rata 38\% (kurang).

f) Siswa yang berani dan aktif dalam mengemukakan pendapat dan menjawab pertanyaaan dari $25 \%$ dan 33\% (kurang) menjadi 38\% (kurang) dengan rata-rata 38\% (kurang).

g) Siswa yang berani tampil mempresentasikan hasil diskusi untuk mewakili kelompok dari $40 \%$ dan 52\% ( cukup) menjadi $64 \%$ (baik) dengan rata-rata $52 \%$ (cukup) .

h) Siswa yang kurang aktif dan tidak serius dalam belajar dari $42 \%$ dan 33\% (kurang) menjadi $25 \%$ (cukup) dengan rata-rata $33 \%$ (kurang).

Berdasarkan data di atas, dapat dipahami bahwa siswa yang aktif pada siklus I sudah mulai menampakkan peningkatan aktivitas belajar. Namun, pada siswa yang menerima bantuan teman atau memberi bantuan kepada teman yang belum faham/ mengerti, berani dan aktif dalam mengemukakan pendapat dan menjawab pertanyaan serta siswa yang berani tampil mempresentasikan hasil diskusi untuk mewakili kelompok masih kurang dan ada siswa yang masih belum aktif dalam berdiskusi. Berdasarkan hasil tersebut, dapat dipahami bahwa pada siklus I sudah mulai terlihat peningkatan aktivitas belajar siswa. Selama proses pembelajaran pada siklus I kekurangaktifan siswa terlihat pada siswa yang menerima bantuan teman atau memberi bantuan kepada teman yang belum paham/ mengerti, berani dan aktif dalam mengemukakan pendapat dan menjawab pertanyaan serta siswa yang berani tampil mempresentasikan hasil diskusi untuk mewakili kelompok. Berdasarkan data yang diperoleh dan masukan dari observer melalui catatan lapangan, maka peneliti merasa perlu melanjutkan pada siklus ke II. Selanjutnya, hasil rata-rata aktivitas belajar siswa pada siklus II dapat dilihat dari persentase rata-rata siswa aktif dapat dilihat dari uraian berikut:

a) Siswa yang aktif memperhatikan dengan sungguh-sungguh dari $57 \%$ (cukup) dan $75 \%$ (baik) menjadi $80 \%$ ( baik) dengan rata-rata $78 \%$ (baik). 
b) Siswa yang aktif bertanya/ menjawab pertanyaan pada saat pembelajaran dari $63 \%$ dan $71 \%$ (baik) menjadi $70 \%$ (baik) dengan rata-rata $67 \%$ (baik).

c) Siswa yang aktif mencatat dan membuat kesimpulan dari $83 \%$ (sangat baik) dan 80\% (baik) menjadi $86 \%$ (sangat baik) denagn rata-rata $83 \%$ (sangat baik).

d) Siswa yang aktif bekerja secara berkelompok dengan teman sekelompok dari $67 \%$ dan $79 \%$ (baik) menjadi $85 \%$ (sangat baik) dengan rata-rata $77 \%$ (baik).

e) Siswa yang menerima bantuan teman atau memberi bantuan kepada teman yang belum faham/ mengerti dari $61 \%$ dan $73 \%$ ( baik) menjadi $86 \%$ (sangat baik) dengan rata-rata $73 \%$ ( baik).

f) Siswa yang berani dan aktif dalam mengemukakan pendapat dan menjawab pertanyaaan dari $58 \%$ dan 80 $\%$ ( baik) menjadi $85 \%$ (sangat baik) dengan rata-rata $74 \%$ (baik).

g) Siswa yang berani tampil mempresentasikan hasil diskusi untuk mewakili kelompok dari $71 \%$ dan $85 \%$ ( sangat baik) menjadi $93 \%$ (sangat baik) dengan rata-rata $83 \%$ (sangat baik).

h) Siswa yang kurang aktif dan tidak serius dalam belajar dari $21 \%$ dan $13 \%$ (sangat baik) menjadi $4 \%$ (sangat baik) dengan rata-rata $13 \%$.

Secara keseluruhan pada siklus I dan siklus II, terjadi peningkatan aktivitas siswa yaitu pada siklus II. Hal ini disebabkan karena siswa bersemangat dalam belajar dan lebih mengerti jika dapat belajar berkelompok sehingga siswa yang mempunyai kemampuan lebih dapat membantu temannya yang lain dalam kelompoknya dan kemudian dapat mempresentasikan hasil diskusi masing-masing kelompok di depan kelas. Selain itu, indikator tersebut menyimpulkan bahwa penerapan model pembelajaran kooperatif tipe group investigation dapat meningkatkan aktivitas belajar IPA Terpadu siswa kelas IX.2 SMPN 1 IX Koto Sungai Lasi, Kabupaten Solok. Dari hasil diskusi masing-masing siswa dapat menyimpulkan materi dan dicatat dalam buku catatan. Rata-rata kenaikan persentase siklus I dengan siklus II adalah 45\% dengan $68 \%$ yaitu 23 $\%$.

Tabel. 1 Rata-rata kenaikan persentase siklus I dengan siklus II

\begin{tabular}{|c|c|c|c|c|}
\hline \multirow[t]{2}{*}{ No. } & \multirow{2}{*}{$\begin{array}{c}\text { Aspek Aktivitas Siswa yang } \\
\text { Diamati }\end{array}$} & \multicolumn{3}{|c|}{ NILAI RATA-RATA } \\
\hline & & Siklus I & Siklus II & Peningkatan \\
\hline 1. & $\begin{array}{l}\text { Memperhatikan dengan } \\
\text { sungguh - sungguh }\end{array}$ & $44 \%$ & $71 \%$ & $27 \%$ \\
\hline 2. & $\begin{array}{l}\text { Aktif bertanya/ menjawab } \\
\text { dalam pembelajaran }\end{array}$ & $50 \%$ & $67 \%$ & $17 \%$ \\
\hline 3. & $\begin{array}{l}\text { Aktif mencatat dan membuat } \\
\text { kesimpulan }\end{array}$ & $63 \%$ & $83 \%$ & $20 \%$ \\
\hline 4. & $\begin{array}{l}\text { Aktif bekerja secara } \\
\text { berkelompok dengan teman } \\
\text { sekelompok }\end{array}$ & $49 \%$ & $77 \%$ & $28 \%$ \\
\hline 5 . & $\begin{array}{l}\text { Menerima bantuan teman atau } \\
\text { memberi bantuan kepada } \\
\text { teman yang belum faham/ } \\
\text { mengerti. }\end{array}$ & $38 \%$ & $73 \%$ & $36 \%$ \\
\hline 6. & $\begin{array}{l}\text { Berani dan aktif dalam } \\
\text { mengemukakan pendapat dan } \\
\text { menjawab pertanyaaan }\end{array}$ & $32 \%$ & $74 \%$ & $42 \%$ \\
\hline 7. & $\begin{array}{l}\text { Berani tampil } \\
\text { mempresentasikan hasil diskusi } \\
\text { untuk mewakili kelompok. }\end{array}$ & $52 \%$ & $83 \%$ & $31 \%$ \\
\hline 8. & $\begin{array}{l}\text { Siswa yang kurang aktif dan } \\
\text { tidak serius dalam belajar. }\end{array}$ & $33 \%$ & $13 \%$ & $21 \%$ \\
\hline Jumlah & ata-rata Siswa aktif & $45 \%$ & $68 \%$ & $23 \%$ \\
\hline
\end{tabular}


Berdasarkan tabel 1 di atas, dapat disimpulkan bahwa terjadi peningkatan signifikan terhadap aktivitas belajar siswa setelah diterapkan model pembelajaran kooperatif tipe group investigation. Selanjutnya, data lengkap mengenai peningkatan tersebut dapat dilihat dari grafik berikut ini.

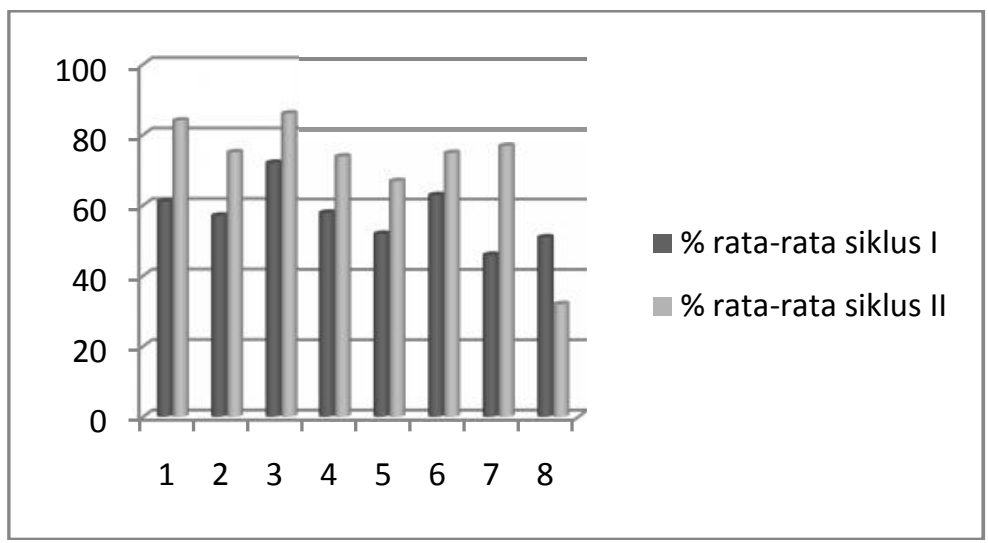

Grafik 1. Diagram Batang Aktivitas Siswa Selama Pembelajaran Siklus I dan Siklus II

Dari analisis data hasil kegiatan siswa ternyata telah terjadi peningkatan aktivitas siswa dan hasil belajar siswa serta aspek yang diteliti terlihat dari peningkatan pada siklus I dan siklus II. Menurut Sujana (1995:5), peningkatan aktivitas siswa yang ikut berdiskusi disebabkan adanya teman yang ikut aktif dalam kelompok serta adanya penilaian langsung oleh observer, maka siswa termotivasi untuk ikut serta dalam berdiskusi selain itu sistem belajar berkelompok dengan teman sebaya banyak membantu siswa yang kurang mengerti belajar kepada siswa yang lebih mengerti (pintar) dengan cara mereka masing-masing sedangkan hasil belajar yang diperoleh yang telah peneliti dilakukan maka akan dibahas beberapa hal yang berhubungan dengan hasil penelitian yang telah dilaksanakan. Hal-hal yang telah menampakkan peningkatan aktivitas siswa setelah diadakan tindakan pada siklus I dan siklus II sebagaimana ditunjukkan pada grafik gambar.

\section{Peningkatan Hasil Belajar}

Berdasarkan hasil evaluasi terhadap kemampuan siswa memahami konsep melalui evaluasi yang diberikan, diperoleh data seperti yang dinyatakan pada tabel berikut.

Tabel 2. Daftar Nilai Tes Hasil Belajar IPA Siklus 1 dan Siklus 2

\begin{tabular}{llllll}
\hline \multirow{2}{*}{ No. } & \multicolumn{1}{c}{ Nama Siswa } & \multicolumn{3}{c}{ Nilai } \\
\cline { 3 - 6 } & & \multicolumn{1}{c}{ Siklus I } & Siklus II & Kenaikan & \% Kenaikan \\
1. & Afrinelita & 55.0 & 85.0 & 30.0 & 54.5 \\
\hline 2. & Defri Yulianto & 50.0 & 85.0 & 35.0 & 70.0 \\
\hline 3. & Denni Alvialdi & 62.5 & 82.5 & 20.0 & 32.0 \\
\hline 4. & Devi Yatmilsa & 70.0 & 87.5 & 17.5 & 25.0 \\
\hline 5. & Diana Devianti & 63.8 & 82.5 & 18.8 & 29.4 \\
\hline 6. & Elsa Krismonika & 70.0 & 87.5 & 17.5 & 25.0 \\
\hline 7. & Elvina Sagita & 61.3 & 87.5 & 26.3 & 42.9 \\
\hline 8. & Febri Handiki & 62.5 & 87.5 & 25.0 & 40.0 \\
\hline 9. & Feri Eka Candra & 75.0 & 87.5 & 12.5 & 16.7 \\
\hline 10. & Indah Yudia Triadi & 88.8 & 93.8 & 5.0 & 5.6 \\
\hline 11. & Islam Yude Medina & 86.3 & 93.8 & 7.5 & 8.7 \\
\hline 12. & Juniati Ifana & 72.5 & 87.5 & 15.0 & 20.7 \\
\hline 13. & Khairun Nissa & 42.5 & 80.0 & 37.5 & 88.2 \\
\hline 14. & Liarani & 46.3 & 83.8 & 37.5 & 81.1 \\
\hline 15. & M. Syukria Yusra R & 52.5 & 80.0 & 27.5 & 52.4 \\
\hline
\end{tabular}




\begin{tabular}{llllll}
\hline 16. & Novia Lovena & 67.5 & 85.0 & 17.5 & 25.9 \\
17. & Rezi Okta Vernando & 55.0 & 85.0 & 30.0 & 54.5 \\
18. $\quad$ Rian Hidayat & 45.0 & 82.5 & 37.5 & 83.3 \\
19. Riki Elfitra & 50.5 & 85.0 & 34.5 & 68.3 \\
\hline 20. Sandi Alfianda & 43.8 & 82.5 & 38.8 & 88.6 \\
21. Afrinelita & 51.3 & 83.8 & 32.5 & 63.4 \\
\hline Rata - rata & 60.6 & 85.5 & 24.9 & 46.5 \\
\hline
\end{tabular}

Berdasarkan tabel 2 diatas nilai rata-rata pemahaman konsep siswa pada siklus I adalah 60,6 dengan nilai terendah 42,5 dan nilai tertinggi 88,8. Menurut catatan lapangan dari observer tentang pelaksanaan penelitian pada siklus I, diperoleh masukan sebagai berikut:

1. Pada saat diskusi masih ada siswa yang belum berani melibatkan diri, untuk itu guru harus berusaha memancing agar siswa tersebut berani dan memotivasi siswa untuk mau bertanya atau menjawab pertanyaan.

2. Pada saat proses pembelajaran masih ada siswa yang belum aktif sedikitpun, untuk itu, perlu adanya bimbingan dan motivasi lebih dari guru atau pun penjelasan yang memungkinkan untuk siswa agar mereka tahu akan tugas dan kewajibannya. Hal tersebut dapat dilihat dari grafik berikut ini.

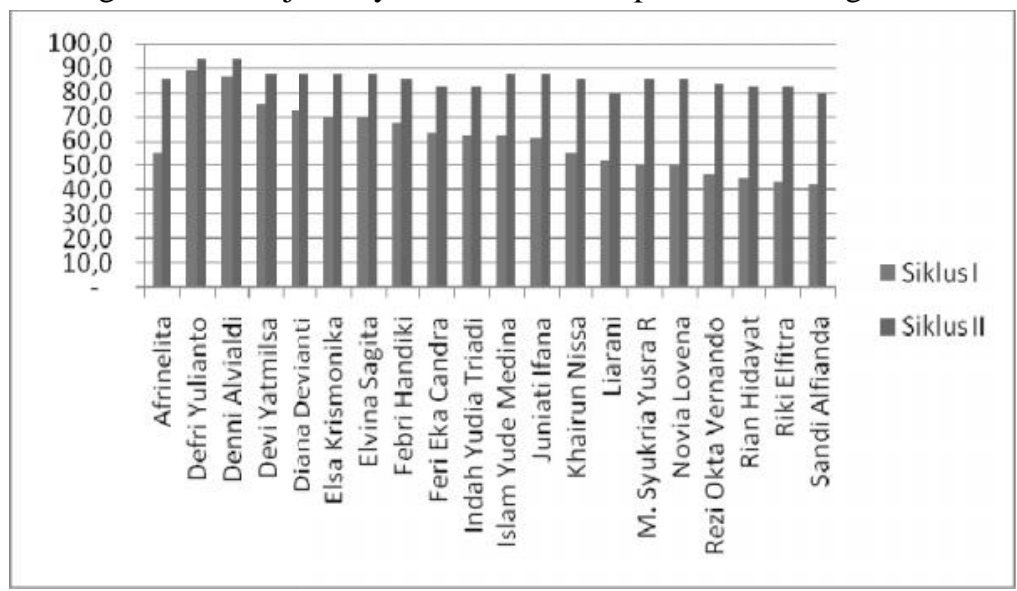

Grafik 2. Diagram Batang Hasil Belajar Siswa Selama Pembelajaran Siklus I dan Siklus II

Dari grafik di atas, dapat dijelaskan bahwa nilai rata-rata pemahaman konsep pada siklus II 85,5 dengan nilai tertinggi 93,8 dan nilai terendah 80. Secara keseluruhan, pada siklus I dan siklus II terjadi peningkatan hasil belajar IPA Terpadu siswa tentang Kemagnetan yaitu pada siklus II. Hal ini disebabkan karena siswa dapat membiasakan diri dengan belajar berkelompok yang dapat membuat siswa lebih mengerti dengan belajar bersama dengan teman sekelompok (sebaya) yang materinya sudah ditentukan oleh guru terlebih dahulu sehingga timbul keinginan untuk meningkatkan hasil belajar.

Berdasarkan hasil yang dicapai baik dari aktivitas maupun hasil belajar, maka sampai pada siklus II, hasil dari perlakuan/tindakan yang dilakukan sudah mencapai hasil yang memuaskan. Dalam proses pembelajaran yang dilakukan oleh peneliti menunjukkan pengaruh yang baik terhadap perubahan cara belajar siswa. Siswa yang selama ini belajar kurang semangat sekarang cukup antusias untuk mengerjakan beban tugas yang diberikan kepadanya sehingga partisipasi siswa dalam bekerja sama pada kelompoknya, seperti bertanya, menjawab pertanyaan dari teman, memberikan masukan atau pendapat tehadap hasil kerja orang lain meningkat. Mereka telah mau menghargai pendapat dari teman-temannya. Terjadinya interaksi antara siswa yang satu dengan siswa yang lain, dan antara siswa dengan peneliti. Fenomena ini memberikan pengaruh yang cukup baik kepada hasil belajar siswa, sehingga target berupa indikator keberhasilan yang telah ditetapkan tercapai. Secara kuantitatif persentase kenaikan aktivitasi siswa pada siklus I mencapai ratarata 45, sedangkan pada siklus II tingkat persentase kenaikan aktivitasi siswa semakin baik, yaitu mencapai 
rata-rata 68. Keadaan ini memberikan makna bahwa tindakan pembelajaran untuk siklus berikutnya tidak diperlukan lagi.

\section{SIMPULAN DAN SARAN}

Berdasarkan hasil penelitian dapat disimpulkan bahwa melalui model pembelajaran cooperatif learning dengan tipe group investigation dapat meningkatkan aktivitas dan hasil belajar IPA Terpadu siswa kelas IX.2 SMPN 1 IX Koto Sungai Lasi Kab. Solok Tahun Pelajaran 2015/ 2016. Dengan meningkatkan aktivitas dan hasil belajar keaktifan siswa dalam menjawab pertanyaan guru dan dapat membantu pasangan kelompoknya yang belum faham terhadap materi ataupun permasalahan yang ditampilkan oleh guru. Oleh sebab itu, perlu disarankan dua hal, yaitu (1) guru-guru IPA dalam proses pembelajaran untuk dapat menggunakan model pembelajaran cooperatif learning dengan tipe group investigation yang dapat meningkatkan aktivitas dan hasil belajar siswa, (2) agar pembelajaran IPA Terpadu lebih menarik dan menimbulkan semangat serta keaktifan siswa guru sebaiknya memvariasikan model, metode, dan pendekatan pembelajaran yang sesuai dengan meteri dan kondisi siswa sehingga tujuan pembelajaran dan hasil belajar yang maksimal dapat tercapai.

\section{DAFTAR RUJUKAN}

Agus, Suprijono. (2010). Cooperative Learning. Yogyakarta: Pustaka Pelajar.

Aritonang, K. T. (2008). Minat dan motivasi dalam meningkatkan hasil belajar siswa. Jurnal Pendidikan Penabur, 7(10), 11-21.

Bern, G. R dan Erickson, M. P. (2001). "Contextual Teaching and Learning: Preparing Students for The New Economy." Journal The Highlight Zone.

Depdiknas. (2003). http://teknologipendidikan.wordpress.com. Diakses tanggal 28 Maret 2011.

Hasan, Said Hamid. (1996). Pendidikan Ilmu-ilmu Sosial. Bandung: Rineka.

Kontekstual, m. P. P. (2011). Penelitian tindakan kelas.

Mappeasse, M. Y. (2009). Pengaruh Cara dan Motivasi Belajar Terhadap Hasil Belajar Programmable Logic Controller (PLC) Siswa Kelas III Jurusan Listrik SMK Negeri 5 Makassar. Jurnal Medtek, 1(2), 7-12.

Muldayanti, N. D. (2013). Pembelajaran Biologi Model STAD dan TGT ditinjau dari Keingintahuan dan Minat Belajar Siswa. Jurnal Pendidikan IPA Indonesia, 2(1).

Nurseto, T. (2012). Membuat media pembelajaran yang menarik. Jurnal Ekonomi \& Pendidikan, 8(1).Pusat Bahasa. 1989. Kamus Besar Bahasa Indonesia. Jakarta: Balai Pustaka.

Sakti, I., Yuniar Mega, P., \& Eko, R. (2012). Pengaruh model pembelajaran langsung (Direct Instruction) melalui media animasi berbasis macromedia flash terhadap minat belajar dan pemahaman konsep fisika siswa di SMA Plus Negeri 7 Kota Bengkulu. EXACTA, 10(1), 1-10.

Sandjaja, S. (2001). Pengaruh keterlibatan orang tua terhadap minat membaca anak ditinjau dari pendekatan stres lingkungan. Psikodimensia kajian ilmiah psikologi, 2(1), 17-25.

Slavin, E Robert. (2008). Cooperative Learning (Teori, Riset dan Praktik). Bandung : Nusa Media.

Sudjana, Nana. (1995). Penilaian Hasil Proses Belajar Mengajar. Bandung: PT. Remaja Rosda Karya.

Suhito. (2000). Interaksi Belajar Mengajar. Jakarta: Depdiknas.

Sulasti, N. W. (2013). Penerapan Model Pembelajaran Kooperatif Tipe Group Investigation (GI) Untuk Meningkatkan Aktivitas dan Hasil Belajar Siswa Dalam Pelajaran PKn Di Kelas XI IPA 1 SMA Negeri 1 Sawan Tahun Ajaran 2012/2013. Jurnal Jurusan Pendidikan PKn, 1(4).

Wasti, S. (2013). Hubungan Minat Belajar Dengan Hasil Belajar Mata Pelajaran Tata Busana Di Madrasah Aliyah Negeri 2 Padang. E-Journal Home Economic and Tourism, 2(1).

Winkel. (1996). Psikologi Pengajaran. Jakarta: PT. Gramedia Widiasarana Indonesia. 